will carry the necessary improvements over such a period of years, during which time the foreign trade of the country will be seriously affected, that it is most important for the interests of the people of Ecuador that the government obtain the money to do the needed work at once.

Certain parts of the country are still without proper railroad facilities, even taking into consideration their present undeveloped state, and if a comparatively few miles of road could be built, it should prove of great benefit to the people. In order to refund all outstanding obligations, complete the sanitation of Guayaquil and make the railroad system thoroughly effective, it is figured that Ecuador will be obliged to borrow about $\$ 30,000,000$.

\title{
EL SALVADOR
}

\section{By Frederick F. Searing, \\ Paterson, N. J.}

The area of Salvador is 7,225 square miles; it is about the size of the state of New Jersey which has an area of 7,525 square miles and has a population of $1,250,000$. Its density of population per square mile is just about one-half that of the state of New Jersey. Almost all of the available surface of the country is under cultivation. Nature seems to have assembled and combined all of the various elements that are necessary to the successful production of coffee, about $65,000,000$ pounds of coffee being exported each year.

Salvador has the best record of any of the Central American republics for looking after its credit. Its public finances heretofore have been in charge of the English, the only foreign loan that Salvador ever issued having been floated in London in 1908. This loan amounted to $£ 1,000,000$, sterling. It bears interest at the rate of 6 per cent per annum and a sinking fund is provided, consisting of $2 \frac{1}{2}$ per cent of the principal amount of the bonds, redeemable in each year. The loan was floated by the London Bank of Mexico and South America and Messrs. Chalmers, Guthrie \& Co. of London. It was listed at once on the London stock exchange and has been regularly traded in on that board ever since. Payments of the interest and sinking fund on account of this loan were regularly made from the date of its issue until the month of August, 1915, when, owing to the decrease in the revenues derived from duties on imports and exports occasioned by the war in Europe, the Minister of Finance made a proposition to the holders of the bonds that they deposit their coupons representing four years' interest on the principal of the loan with the trustees for the loan 
in London, who would issue certificates of the government representing the coupons so deposited, bearing 7 per cent interest. This proposition was accepted by the holders of the bonds and was formally put into effect in the month of December, 1915.

The progress of Salvador is effectually shown by the following figures:

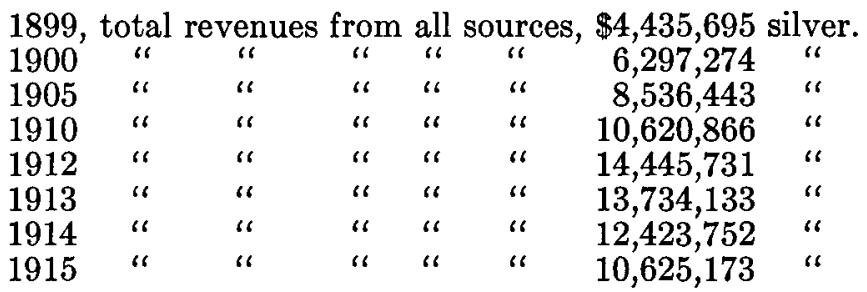

It will be noted that in the year 1899 the total revenues of the government from all sources amounted to $\$ 4,435,695$ silver, and in the year 1912 the revenues of the country had increased to $\$ 14,445,731$ silver. It will also be noted that the revenues for the year 1915 amounted to $\$ 10,625,173$ silver, the decrease having been occasioned by the outbreak of the European war. During the present year the turning point was reached and at the present time the revenues of the country are gradually increasing.

The best opportunity for the employment of capital in Salvador at the present time is in the establishment of a government bank. There are three chartered banks of issue in the republic, and their notes form the paper currency of the country. The government does not issue any paper money. Aside from this, the money is silver coin. The value of the silver dollar or peso is about $42 \frac{1}{2}$ cents American gold. The National Assembly granted a charter for an agricultural bank in the year 1914. The present banking facilities of Salvador are insufficient, and if a new institution were established it would have the hearty support of the government and would unquestionably do a very profitable business. Banking in Salvador is based on the movement of merchandise in and out of the country. This is the safest kind of banking. Rates of interest are good, being greater than those prevailing in the United States, and the security for loans is the best in the world.

Salvador also needs more railways. There are three railways now operating within the republic. The Salvador Railway, which runs from the port of Acajutla to the capital city, San Salvador, with a branch to the city of Santa Ana, in all having a total trackage of about one hundred and fifty kilometers, was built in the year 1899 by an English company. It will be noted by the foregoing figures that in the year 1899 the total revenues of Salvador amounted to but $\$ 4,435,695$ silver, yet in that year the government undertook to pay the English Company an annual cash subsidy of $£ 24,000$ 
sterling for a period of eighteen years, and this pledge the government has regularly and faithfully kept. On the strength of this agreement on the part of the government the English Company was enabled to float its own securities in London. The railroad has been operating successfully ever since. At the present time another railway is in process of construction, running from the port of La Union, on the Gulf of Fonseca at the eastern end of the republic, entirely across the central portion of the country to Guatemala. This railway is one of the links in the Ferrocarril Internacional which is designed to run ultimately all the way to Panama. At the present time about one hundred and fifty kilometers of this line have been finished and are now in operation. The only other railway in the republic is a short line built by local capital, between the capital city, San Salvador, and the city of Santa Tecla, a distance of about fifteen kilometers.

A concession was granted in the year 1914 by the government for the construction of a railway between the capital city, San Salvador, and the port of La Libertad on the Pacific coast, a distance of about fifty kilometers. This railway is really a government enterprise. The government issues bonds to the extent of $\$ 1,500,000$ gold, the proceeds of which are to build the railway. The distance by the English railway from the city of San Salvador to the port of Acajutla is one hundred and five kilometers. The new line will afford a much shorter route to the coast. La Libertad is the natural port of entry for the city of San Salvador, and the construction of this railway will open up a very rich territory and will be of great benefit to the government.

The mineral resources of Salvador have been scarcely touched. There are several English mining companies and one or two American ones that have been operating successfully for a great many years in the eastern part of the republic; but there are vast mineral resources in the mountains to the north bordering on the Hondurean frontier which have not been developed.

Deposits of petroleum in the eastern part of the republic have recently been discovered. A great deal can be done in Salvador by developing the water powers of the country. There are several of these within the republic.

An opportunity is open to enterprising American contractors for the paving of the streets of the principal cities. The city of San Salvador has spent a great deal of time and money in the preparation of plans and details for the paving and sewering of the capital city, and it was about ready to go ahead with this work when the European war broke out.

Salvador occupies a very strategic position among the five Central American republics. The Gulf of Fonseca, which is the only land-locked harbor between San Francisco and Panama, is 
situated at the eastern end of the republic. On the Nicaraguan shore of this gulf the United States government purposes to establish a naval base. The islands within the Gulf of Fonseca belong to Salvador and that of Meanguera commands the entrance to the Gulf. The President of the republic is anxious to see established on this Island a free port similar to that on the Island of Curaçao, off the coast of Venezuela. His idea is that, if warehouses, dry docks and coaling stations for ships were erected on this island, the merchants of foreign countries could ship their goods in bulk to this port, where they would be entered free of duty. By such an arrangement wholesale stocks could be carried in this central place and the different countries supplied from that point. Inasmuch as three of the republics border on the Gulf of Fonseca, the transshipment of goods in small quantities to the respective countries could easily be accomplished. A concession for the establishment of such a port was granted by the National Asembly in the year 1914 .

The opportunity is open to American merchants to capture the entire Pacific trade of Central America by establishing themselves at this time in Salvador. The country has been singularly free from revolutions, the last outbreak of this nature having occurred as far back as 1895 . The republic has a stable government which changes every four years by the ballot instead of the bullet. The people are industrious and the climate is salubrious. There is an entire absence of the fevers peculiar to the countries in the latitude of Salvador on the Atlantic side. This is chiefly because the country is hilly and well drained; also on account of an absence of low-lying marshy lands.

To conclude, Salvador is well worthy of a visit and the serious consideration of American capitalists who may be contemplating investing in Latin American countries.

\section{GUATEMALA}

\section{Bx John Clauusen,}

Manager Foreign Department, The Crocker National Bank of San Francisco.

The Republic of Guatemala, situated East of Mexico, covers an area of about 50,000 square miles, with an estimated population of 2,120,000 inhabitants - the largest of any Central American country - of which 125,000 reside in the capital, Guatemala City. The name "Guatemala" is probably of Aztec origin and is said to mean "Land of the Eagle." The bulk of its people are located in that half of the Republic bordering on the Pacific with few settle- 